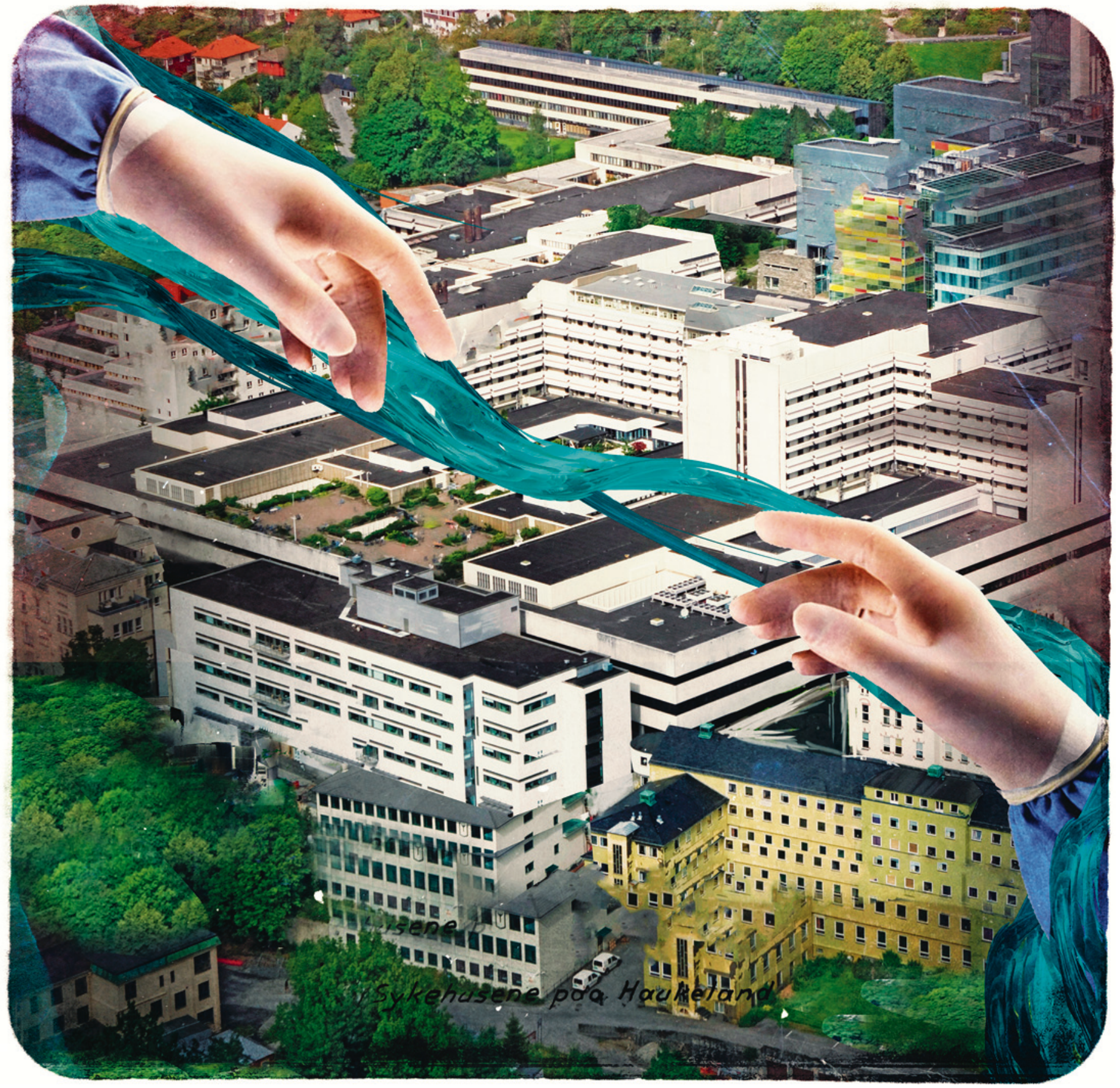

\title{
Haukeland universitetssykehus
} På Haukeland gård begynte man på begynnelsen av 1900 -tallet å føre opp de første byggene som
nå tilhører universitetssykehuset. Etter hvert har bygningsmassen økt betraktelig og representerer
nå en rekke stiler og tidsepoker.

Lokalsykehusområde: 500000 personer
Universitetssykehusområde: 1000000 personer 